\title{
HLA-Promiscuous Th1-Cell Reactivity of MPT64 (Rv1980c), a Major Secreted Antigen of Mycobacterium tuberculosis, in Healthy Subjects
}

\author{
Abu Salim Mustafa \\ Department of Microbiology, Faculty of Medicine, Kuwait University, Kuwait
}

\section{Key Words}

MPT64 - Peripheral blood mononuclear cells • T-cell lines • Th1-cell reactivity $\cdot$ Cytotoxicity

\begin{abstract}
Objective: To determine HLA-promiscuous Th1-cell reactivity of MPT64 (Rv1980c) in healthy humans. Materials and Methods: Peripheral blood mononuclear cells (PBMCs) were obtained from healthy subjects $(n=61)$ and HLA typed genomically. PBMCs were tested for Th1-cell reactivity (antigen-induced proliferation and interferon- $\gamma$ secretion) with complex antigens (whole cells, culture filtrate and cell walls) and single secreted antigens (Ag85B, MPT64 and MPB70) of Mycobacterium tuberculosis. In addition, culture-filtrateinduced T-cell lines were established from PBMCs of 14 donors and tested with the above antigens in Th1-cell assays. Furthermore, $3 \mathrm{~T}$-cell lines were tested for cytotoxic activity against MPT64-pulsed monocytes/macrophages, and a Tcell line was analysed for HLA restriction in antigen presentation using anti-HLA class I and class II monoclonal antibodies and HLA-DR-typed antigen-presenting cells. Results: PBMCs showed strong Th1-cell reactivity with all of the complex mycobacterial antigens, whereas MPT64 induced moderate Th1-cell reactivity, which was comparable to the reactivity induced by other previously characterized secreted antigens of M. tuberculosis, i.e. Ag85B and MBP70. Furthermore, HLA heterogeneity of the responding donors suggested
\end{abstract}

\section{KARGER}

Fax +4161306 1234

E-Mail karger@karger.ch

www.karger.com
(C) 2009 S. Karger AG, Basel

$1011-7571 / 09 / 0185-0385 \$ 26.00 / 0$

Accessible online at:

www.karger.com/mpp that MPT64 was presented to Th1 cells promiscuously. Testing of the T-cell lines confirmed that Th1 cells contributed to the promiscuous antigen-specific reactivity observed with PBMCs and exhibited cytotoxic activity against MPT64pulsed monocytes/macrophages. In addition, a T-cell line investigated for HLA restriction analysis showed that MPT64 was presented to T cells in association with HLA-DR molecules in a promiscuous manner. Conclusion: MPT64 is promiscuously recognized by human Th1 cells with cytotoxic activity and therefore deserves consideration as a candidate vaccine against tuberculosis in humans.

Copyright $\odot 2009$ S. Karger AG, Base

\section{Introduction}

Tuberculosis (TB) is among the top 10 causes of worldwide mortality and has been declared a global emergency by the World Health Organization. The global problem of TB is worsening due to the spread of multi-drug- and extensively drug-resistant strains of Mycobacterium tuberculosis, and its strong association with HIV and AIDS [1]. About one third of the world population is infected with M. tuberculosis with 8 million new cases and 2 million deaths annually [1]. In Kuwait, about 550 cultureconfirmed cases of TB are diagnosed each year [2]. The impact of current efforts to reduce the global incidence of TB is less than expected, and improved diagnostic and

Prof. Abu Salim Mustafa

Department of Microbiology, Faculty of Medicine

Kuwait University, PO Box 24923

Safat 13110 (Kuwait)

Tel. +9652498 6505, Fax +965 2533 2719, E-Mail abusalim@hsc.edu.kw 
curative efforts should be combined with additional preventive efforts [1]. It is expected that the development of safe and effective vaccines for preventive treatment would revolutionize TB control [1]. Thus, there is an urgent need to identify antigens of $M$. tuberculosis, which could have potential as a safe vaccine to control TB.

Among the candidates considered useful for the development of new anti-TB vaccines are antigens secreted by $M$. tuberculosis during active growth $[3,4]$. The culture filtrate of $M$. tuberculosis (MTCF), which is extremely rich in secreted antigens, has been shown to be protective in animals immunized with it and challenged with virulent M. tuberculosis [5]. However MTCF is a complex mixture of a large number of secreted antigenic proteins of M. tuberculosis [6], and, therefore, it is required that single antigens in MTCF, which have vaccine potential, be identified.

The analyses of MTCF for single proteins identified a few predominantly secreted proteins, including MPT64 (Rv1980c) [6], with an apparent molecular mass of 24 $\mathrm{kDa}$. Previous studies have shown that MPT64 is recognized by TB patients in immunological assays [7-11]. In addition, MPT64 has also been shown to protect against M. tuberculosis infection in mouse models of TB $[12,13]$. However, to qualify as a candidate vaccine in humans, an antigen, e.g. MPT64, should be recognized by Th1 cells having cytotoxic activity, because these types of $\mathrm{T}$ cells play a major role in protection against TB $[14,15]$. Furthermore, since Th1 cells recognize mycobacterial antigens mostly in association with highly polymorphic HLA-DR molecules [16], the antigens selected as anti-TB vaccine candidates should be presented to Th1 cells in an HLA-DR-promiscuous fashion [17].

In this study, MPT64 was studied for Th1-cell reactivity using peripheral blood mononuclear cells (PBMCs) and T-cell lines established from PBMCs of HLA-DRheterogeneous healthy subjects living in Kuwait. In addition, cytotoxic activity of T-cell lines was determined using MPT64-pulsed monocytes/macrophages, and HLA restriction analysis with a T-cell line was performed using anti-HLA class I and class II monoclonal antibodies and HLA-DR-typed autologous as well as allogeneic antigen-presenting cells (APCs).

\section{Materials and Methods}

Complex and Purified Single Antigens of M. tuberculosis

The complex mycobacterial antigens used in this study were irradiated whole-cell M. tuberculosis H37Rv [18], MTCF enriched for secreted antigens and purified M. tuberculosis cell walls [19].
MTCF and M. tuberculosis cell walls were kindly provided by Dr. P.J. Brennan (Colorado State University, Colo., USA) through the repository of tuberculosis research materials, NIH contract No. AI-25147, USA. The purified single antigens, antigen 85B (Ag85B) or MPT59 (lot 12455A2), MPT64 (lot 6523A2) and MPB70 (lot $3948 \mathrm{~F}$ ) were prepared from the mycobacterial culture filtrates, as previously described [9].

\section{Study Subjects and Isolation of PBMCs}

The study subjects were 61 healthy subjects randomly selected from the group of blood donors at the Central Blood Bank, Kuwait. All the donors were vaccinated with $M$. bovis bacilli Calmette-Guérin (BCG) Pasteur and were positive for the $M$. tuberculosis purified protein derivative skin test, but none had a previous history of TB. An informed consent was obtained from all the subjects, and the study protocol was approved by the Ethical Committee of the Faculty of Medicine, Kuwait University, Kuwait. PBMCs were separated from the blood and buffy coats by density centrifugation according to standard procedures [20,21]. The cells were finally suspended in $5 \mathrm{ml}$ complete tissue culture medium [RPMI $1640+10 \%$ human AB serum + penicillin (100 $\mathrm{U} / \mathrm{ml})+$ streptomycin $(100 \mu \mathrm{g} / \mathrm{ml})+$ gentamycin $(40 \mu \mathrm{g} / \mathrm{ml})+$ fungizone $(2.5 \mu \mathrm{g} / \mathrm{ml})$ ], tested for viability ( $>98 \%$ viable by trypan blue exclusion assay) and counted in a Coulter counter (Coulter Electronics Ltd., Luton, UK) [22].

\section{HLA Typing of PBMCs}

PBMCs were HLA typed genomically by using sequence-specific primers in polymerase chain reaction, as described previously $[23,24]$. In brief, an HLA-DR 'low-resolution' kit containing the primers to type for $D R B 1, D R B 3, D R B 4$ and $D R B 5$ alleles was purchased from Dynal AS (Oslo, Norway) and used in polymerase chain reaction as specified by the manufacturer. DNA amplifications were carried out in a Gene Amp polymerase chain reaction system 2400 (Perkin-Elmer, Cetus), and the amplified products were analysed by agarose gel electrophoresis, using standard procedures [25]. Serologically defined HLA-DR specificities were determined from the genotypes by following the guidelines provided by Dynal AS.

\section{Antigen-Induced Proliferation and Interferon- $\gamma$ Secretion by} PBMCs

The assays for antigen-induced proliferation and interferon- $\gamma$ (IFN- $\gamma$ ) secretion by PBMCs were performed by using standard procedures $[26,27]$. In brief, PBMCs $\left(2 \times 10^{5}\right.$ cells/well $)$ were seeded into the wells of 96-well tissue culture plates (Nunc, Roskilde, Denmark). Antigens were added to the wells in triplicate, and the control wells lacked antigen. The plates were incubated at $37^{\circ} \mathrm{C}$ in a humidified atmosphere of $5 \% \mathrm{CO}_{2}$ and $95 \%$ air. On day $6,100 \mu \mathrm{l}$ of supernatants from each well were collected for the IFN- $\gamma$ assay, and the remaining cultures were pulsed with $1 \mu \mathrm{Ci}$ of $\left[{ }^{3} \mathrm{H}\right]$ thymidine (Amersham Life Sciences, Little Chalfont, $\mathrm{UK})$ in $50 \mu \mathrm{l}$ complete medium, harvested on filter mats with a Skatron harvester (Skatron Instruments AS, Oslo, Norway) and the amount of radioactivity incorporated was measured by liquid scintillation counting using standard procedures [28]. The radioactivity incorporated was obtained as counts per minute (cpm). Cellular proliferation results were presented as stimulation index (SI), which is defined as follows: $\mathrm{SI}=$ median cpm in antigenstimulated cultures/median cpm in cultures without antigen. An 
SI $>2$ was considered a positive proliferative response to a given antigen $[18,22]$.

The amounts of IFN- $\gamma$ in the supernatants were quantified by using immunoassay kits (Coulter/Immunotech SA, Marseille, France) as specified by the manufacturer. The detection limit of the IFN- $\gamma$ assay kit was $0.4 \mathrm{IU} / \mathrm{ml}$. Secretion of IFN- $\gamma$ in response to a given antigen was considered positive with $\mathrm{E} / \mathrm{C}>2(\mathrm{E} / \mathrm{C}=$ IFN- $\gamma$ concentration in cultures stimulated with antigen/IFN- $\gamma$ concentration in cultures without antigen) and IFN- $\gamma$ concentration $\geq 1.5 \mathrm{IU} / \mathrm{ml}[22,27]$.

Interpretation of Antigen-Induced Proliferation and IFN- $\gamma$ Secretion by PBMCs and Statistical Analysis

An antigen was considered a strong, moderate or weak stimulator of PBMCs in proliferation and IFN- $\gamma$ responses based on percent positives. The responses were considered strong with percent positive $\geq 60$, moderate with percent positive from 40 to $<60$ and weak with percent positive $<40[18,21]$. The statistical analysis, to determine significant differences $(\mathrm{p}<0.05)$ in percent positives in response to various antigens in antigen-induced proliferation and IFN- $\gamma$ secretion assays, was performed by the twosided $\mathrm{Z}$ test using Epical 2000 version 1.02.

\section{Establishment and Antigen Reactivity of T-Cell Lines}

T-cell lines were established from PBMCs of 14 donors after stimulation with MTCF and propagated in the presence of human interleukin 2, as described previously [29, 30]. The T-cell lines were tested for antigen-induced proliferation in the presence of autologous and allogeneic HLA-typed APCs, according to standard procedures [29]. In brief, adherent cells obtained from irradiated (24 Gy) PBMCs (seeded into the wells of 96-well plates at $1 \times 10^{5}$ cells/well) were used as APCs. The T-cell lines were added to the wells at a concentration of $5 \times 10^{4}$ cells/well. Antigens were added in triplicate at a final concentration of $5 \mu \mathrm{g} / \mathrm{ml}$. The plates were incubated at $37^{\circ} \mathrm{C}$ in an atmosphere of $5 \% \mathrm{CO}_{2}$ and $95 \%$ air. On day $3,100-\mu l$ supernatants from each well were collected and assayed for IFN- $\gamma$ concentration using the procedures described above for PBMCs. The remaining cultures were pulsed with $1 \mu \mathrm{Ci}\left[{ }^{3} \mathrm{H}\right]$ thymidine, harvested on filter mats, and the radioactivity incorporated was determined by liquid scintillation counting, as described above for PBMCs.

\section{Cytotoxicity Assay}

The cytotoxic activity of T-cell lines against MPT64-pulsed monocytes/macrophages was assessed by the neutral red release assay according to standard procedures $[29,30]$. In brief, adherent monocytes/macrophages from $1 \times 10^{6}$ autologous irradiated PBMCs in 24-well Costar plates were pulsed with MPT64. The Tcell lines were added at a concentration of $2 \times 10^{5}$ cells/well. After 7 days of incubation at $37^{\circ} \mathrm{C}$, the wells were washed to remove non-adherent $\mathrm{T}$ cells, and the macrophages were allowed to take up neutral red for $30 \mathrm{~min}$. The dye taken up by macrophages was released by adding $0.5 \mathrm{ml}$ of $0.05 \mathrm{M}$ acetic acid in $50 \%$ ethanol. The results are expressed as percent cytotoxicity, which was calculated from the spectrophotometric measurement of optical density at $540 \mathrm{~nm}\left(\mathrm{OD}_{540}\right)$ according to the following formula: percent cytotoxicity $=\left[\left(\mathrm{OD}_{540}\right.\right.$ control $-\mathrm{OD}_{540}$ experimental $) / \mathrm{OD}_{540}$ control] $\times 100$, where $\mathrm{OD}_{540}$ control $=\mathrm{OD}_{540}$ of cultures with adherent cells plus T cells, and $\mathrm{OD}_{540}$ experimental $=\mathrm{OD}_{540}$ of cultures with adherent cells plus T cells plus MPT64.

HLA-Promiscuous Th1-Cell Reactivity of MPT64
Inhibition Assays with Monoclonal Anti-HLA Antibodies

Inhibition of antigen-induced proliferation of a T-cell line was studied in the presence of the monoclonal antibodies W6/32 (antiHLA class I) and L243 (anti-HLA-DR) purchased from the American Type Culture Collection, Rockville, Md., USA, and FN81 (anti-HLA-DQ), a gift from S. Funderud, Oslo, Norway, as described previously $[29,30]$. In brief, adherent APCs in the wells of 96-well flat-bottom plates were pre-incubated with the antibodies for $30 \mathrm{~min}$ at $37^{\circ} \mathrm{C}$ in an atmosphere of $5 \% \mathrm{CO}_{2}$ and $95 \%$ air. After pre-incubation, MPT64-induced proliferation of T-cell lines was assayed, as described above. The results were expressed as percent inhibition [1 - (cpm in antigen-stimulated cultures in the presence of antibodies/cpm in antigen-stimulated cultures in the absence of antibodies)] $\times 100$.

\section{Results}

The representative results for antigen-induced proliferation and IFN- $\gamma$ secretion by PBMCs of 5 donors are shown in table 1 . The results from all donors showed that PBMCs responded strongly to all the complex mycobacterial antigens in both assays (93-96\% positives; table 2 ), without significant differences in percent positives to various antigens $(\mathrm{p}>0.05)$, and all of the tested subjects responded to one or more complex antigens (data not shown).

When single antigens were used, strong responses were observed in response to Ag85B (69 and 67\% positives) and moderate responses to MPT64 (51 and 55\% positives) and MPB70 (59 and 51\% positives) in antigeninduced proliferation and IFN- $\gamma$ secretion assays, respectively (table 2). All the complex antigens induced significantly higher percent positives than the single antigens in both assays $(\mathrm{p}<0.05)$, but there were no significant differences among single antigens in either assay $(p>$ 0.05).

HLA-DR typing of the subjects responding to complex as well as single antigens demonstrated that they represented a heterogeneous group of donors expressing DR1, DR2, DR3, DR4, DR5, DR6, DR7, DR10, DR51, DR52 and DR53 molecules (data not shown), thus indicating the permissive and promiscuous nature of MPT64 for recognition by human PBMCs in Th1-cell assays.

The results of testing MTCF-induced T-cell lines, which had a CD3+, CD4+ CD8- phenotype, with various mycobacterial antigens in antigen-induced proliferation assays showed that all of the 14 (100\%) T-cell lines responded to the complex mycobacterial antigens, whereas 10 (71\%), 9 (64\%) and 5 (36\%) of the T-cell lines responded to Ag85B, MPT64 and MPB70, respectively (table 3). Further testing of the MPT64-responding T-cell lines 
Table 1. Antigen-induced proliferation and IFN- $\gamma$ secretion by PBMCs of healthy subjects in response to complex and single secreted antigens of $M$. tuberculosis

\begin{tabular}{|c|c|c|c|c|c|c|c|c|c|c|}
\hline \multirow[t]{3}{*}{ Antigen } & \multicolumn{10}{|c|}{ Antigen-induced response } \\
\hline & \multicolumn{2}{|c|}{ subject 1} & \multicolumn{2}{|c|}{ subject 2} & \multicolumn{2}{|c|}{ subject 3} & \multicolumn{2}{|c|}{ subject 4} & \multicolumn{2}{|c|}{ subject 5} \\
\hline & SI & $\mathrm{IFN}-\gamma$ & SI & IFN- $\gamma$ & SI & IFN- $\gamma$ & SI & IFN- $\gamma$ & SI & IFN- $\gamma$ \\
\hline No antigen & n.a. & 2.0 & n.a. & $<0.4$ & n.a. & $<0.4$ & n.a. & 1.2 & n.a. & $<0.4$ \\
\hline M. tuberculosis & 8.1 & 78 & 5.0 & 31 & 14 & 57 & 163 & 16 & 34 & 30 \\
\hline MTCF & 14 & 72 & 4.5 & 32 & 33 & 67 & 110 & 18 & 2.9 & 20 \\
\hline MTCW & 21 & 81 & 5.5 & 36 & 19 & 54 & 132 & 17 & 27 & 25 \\
\hline MPT59 & n.d. & n.d. & n.d. & n.d. & 3.0 & 4.9 & 20 & 6.0 & 1.5 & 1.0 \\
\hline MPT64 & 2.4 & 27 & 1.2 & $<0.4$ & 1.8 & 5.4 & 40 & 7.0 & 1.6 & 1.2 \\
\hline MPB70 & 0.6 & 2.0 & 4.1 & 14 & 8.0 & 1.5 & 32 & 8.0 & 1.3 & 0.0 \\
\hline
\end{tabular}

Positive responses, i.e. SI $>2$ or $\mathrm{E} / \mathrm{C}>2.0$ and IFN- $\gamma$ concentration $\geq 1.5 \mathrm{IU} / \mathrm{ml}$, are given in italics.

MTCW = M. tuberculosis cell wall; n.a. = not applicable; n.d. = not determined.

Table 2. Overall results of antigen-induced proliferation and IFN- $\gamma$ secretion by PBMCs of healthy subjects in response to complex and single mycobacterial antigens

\begin{tabular}{|c|c|c|c|c|}
\hline \multirow[t]{3}{*}{ Antigen } & \multicolumn{4}{|c|}{ Response of PBMCs } \\
\hline & \multicolumn{2}{|c|}{ proliferation assay $^{1}$} & \multicolumn{2}{|c|}{ IFN- $\gamma$ assay $^{2}$} \\
\hline & $\begin{array}{l}\text { n positive/ } \\
\text { tested }\end{array}$ & $\begin{array}{l}\% \\
\text { positive }\end{array}$ & $\begin{array}{l}\text { n positive/ } \\
\text { tested }\end{array}$ & $\begin{array}{l}\% \\
\text { positive }\end{array}$ \\
\hline M. tuberculosis & $58 / 59$ & 98 & $45 / 48$ & 94 \\
\hline MTCF & $57 / 61$ & 93 & $45 / 48$ & 94 \\
\hline MTCW & $53 / 55$ & 96 & $42 / 44$ & 96 \\
\hline Ag85B & $25 / 36$ & 69 & $16 / 24$ & 67 \\
\hline MPT64 & $31 / 61$ & 51 & $28 / 51$ & 55 \\
\hline MPB70 & $36 / 61$ & 59 & $26 / 51$ & 51 \\
\hline
\end{tabular}

MTCW $=$ M. tuberculosis cell wall.

${ }^{1}$ Positive response was defined as antigen-induced proliferation with an SI $>2$.

${ }^{2} \mathrm{~A}$ response was considered positive with E/C $>2.0$ and IFN- $\gamma$ concentration $\geq 1.5 \mathrm{IU} / \mathrm{ml}$.

from 3 HLA-DR-heterogeneous subjects revealed that all of these T-cell lines were cytotoxic for monocytes/macrophages pulsed with MPT64 and secreted IFN- $\gamma$ in response to MPT64 (table 4).

The results of anti-HLA antibody inhibition assays revealed that only anti-HLA-DR antibodies inhibited MPT64-induced proliferation of the T-cell line in a dosedependent manner (fig. 1). Furthermore, the experiments with a panel of autologous and allogeneic HLA-DR-typed APCs revealed that MTCF, MPT64 and MPB70 were presented to the T-cell line by autologous as well as HLA-DRheterogeneous allogeneic APCs, whereas Ag85B was presented by autologous APCs only (table 5).

\section{Discussion}

In the present study, PBMCs from a large number of healthy subjects were tested for Th1-cell reactivity, i.e. antigen-induced proliferation and/or IFN- $\gamma$ secretion to complex (whole cells, culture filtrate and cell walls) and 3 secreted single antigens (Ag85B, MPT64 and MPB70) of M. tuberculosis. All of the subjects responded to one or more complex $M$. tuberculosis antigens, suggesting that these donors were sensitized to mycobacteria and thus suitable for determining the Th1-cell reactivity of single antigens. The experiments with single secreted antigens of $M$. tuberculosis showed that more than $50 \%$ of them responded to the antigens MPT64, Ag85B and MPB70, with $\mathrm{Ag} 85 \mathrm{~B}$ as the best stimulator (table 2). Ag85B is a cross-reactive mycobacterial antigen [31], whereas MPT64 and MPB70 are specific for M. tuberculosis complex organisms $[32,33]$. Therefore, higher positive responses to Ag85B in healthy subjects living in Kuwait are not surprising because these responses could be due to infection with $M$. tuberculosis, vaccination with $M$. bovis BCG and exposure to non-tuberculous mycobacteria, whereas the positive responses to MPT64 and MPB70 could only be due to infection with $M$. tuberculosis and/or vaccination 
Table 3. Antigen-induced proliferation (SI) of MTCF-induced T-cell lines responding to complex and single secreted antigens of $M$. tuberculosis

\begin{tabular}{lllllll}
\hline \multirow{2}{*}{$\begin{array}{l}\text { T-cell } \\
\text { line }\end{array}$} & HLA-DR & \multicolumn{5}{l}{ SI of T-cell lines in response to } \\
\cline { 3 - 7 } & & M. tuberculosis & MTCF & Ag85B & MPT64 & MPB70 \\
\hline 1 & $4,13,52,53$ & 71 & 68 & 17 & 64 & 62 \\
2 & n.d. & 33 & 52 & 15 & 2.8 & 0.9 \\
3 & $7,14,52,53$ & 75 & 38 & 10 & 7.5 & 1.4 \\
4 & n.d. & 43 & 30 & 17 & 28 & 4.8 \\
5 & $2,6,51,52$ & 2.1 & 4.4 & 17 & 0.8 & 1.0 \\
6 & $7,11,52,53$ & 6.3 & 5.0 & 3.2 & 4.4 & 1.5 \\
7 & 4,53 & 7.6 & 6.5 & 5.2 & 1.1 & 1.2 \\
8 & 7,53 & 18 & 11 & 1.1 & 2.0 & 1.3 \\
9 & 4,53 & 8.2 & 4.8 & 0.9 & 1.8 & 1.1 \\
10 & 7,53 & 16 & 12 & 0.9 & 4.7 & 1.0 \\
11 & 16,51 & 13 & 9.1 & 0.9 & 2.4 & 1.0 \\
12 & $4,13,52,53$ & 306 & 107 & 14 & 1.4 & 23 \\
13 & n.d. & 123 & 96 & 5.5 & 11 & 10 \\
14 & n.d. & 130 & 114 & 14 & 10 & 5.0 \\
\hline Positive/ & & $14 / 14(100 \%)$ & $14 / 14(100 \%)$ & $10 / 14(71 \%)$ & $9 / 14(64 \%)$ & $5 / 14(36 \%)$ \\
tested & & & & & & \\
\hline
\end{tabular}

Positive responses, i.e. SI $>2$, are given in italics. n.d. $=$ Not determined.

Table 4. MPT64-induced IFN- $\gamma$ secretion and cytotoxicity mediated by T-cell lines

\begin{tabular}{|c|c|c|c|c|c|c|}
\hline \multirow[t]{3}{*}{ Antigen } & \multicolumn{6}{|c|}{ T-cell lines from donors expressing HLA-DR molecules } \\
\hline & \multicolumn{2}{|l|}{$4,5,52,53$} & \multicolumn{2}{|l|}{4,53} & \multicolumn{2}{|l|}{$4,6,52,53$} \\
\hline & $\mathrm{IFN}-\gamma, \mathrm{IU} / \mathrm{ml}$ & cytotoxicity, \% & IFN- $\gamma, \mathrm{IU} / \mathrm{ml}$ & cytotoxicity, \% & IFN- $\gamma, \mathrm{IU} / \mathrm{ml}$ & cytotoxicity, \% \\
\hline No antigen & 2.1 & n.a. & 1.1 & n.a. & $<0.4$ & n.a. \\
\hline МРТ64 & 100 & 81 & 24 & 82 & 49 & 82 \\
\hline
\end{tabular}

Positive IFN- $\gamma$ and percent cytotoxicity results (as defined in the Materials and Methods) are given in italics. n.a. $=$ Not applicable.

with $M$. bovis BCG. In Kuwait, M. bovis BCG Pasteur, which lacks the mpt64 gene [34], was used for vaccination of humans. Furthermore, we have previously shown that about $50 \%$ of the blood donors in Kuwait respond to the M.-tuberculosis-specific antigens ESAT-6 and/or CFP-10 [19], which suggests that a significant proportion of donors responding to MPT64 and MPB70 may have been infected with M. tuberculosis. The single antigens Ag85B and MPB70 are among the candidate vaccine antigens against human TB [3] and have been previously characterized for Th1-cell reactivity in healthy humans for
HLA-promiscuous presentation and cytotoxic activity using antigen-reactive T-cell lines etc. [19, 23, 29], whereas MPT64 lacks such a characterization. Therefore, the work in this study was primarily focused on MPT64, and the other two single antigens were used for comparison purposes.

We have used both proliferation and IFN- $\gamma$ assays as read-out for antigen-specific responses of PBMCs and T-cell lines. These assays are considered standard Th1cell assays $[17,21]$. In addition, the importance of IFN- $\gamma$ as the primary Th1 cytokine that mediates protective 


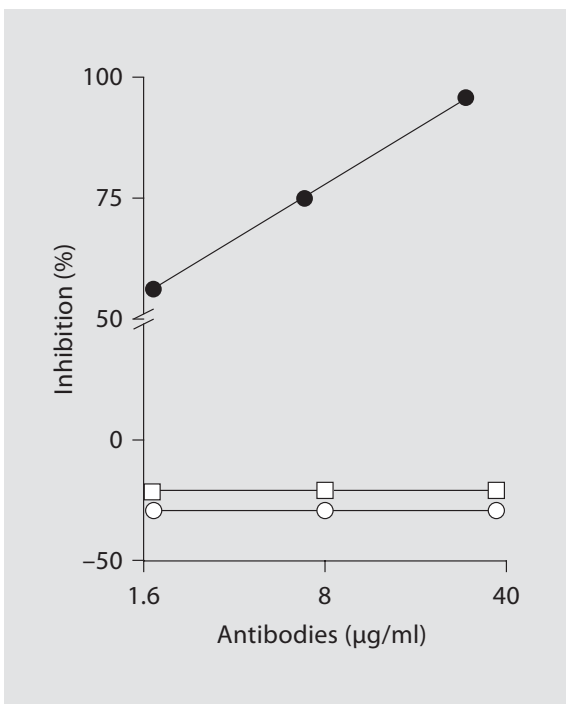

Fig. 1. Inhibition of MPT64-induced proliferation of a T-cell line in the presence of anti-HLA class I and class II monoclonal antibodies. The T-cell line was stimulated with MPT64 in the presence of defined monoclonal antibodies to HLA class I and class II molecules at the concentrations indicated. The percent inhibition (defined in Materials and Methods) of the proliferative response is given for anti-HLA class I (O), anti-HLA-DQ ( $\square$ ) and antiHLA-DR ( $)$ antibodies.

immunity against mycobacterial diseases has been clearly demonstrated in animal models of TB [3]. In humans, strong IFN- $\gamma$ responses have been demonstrated in purified-protein-derivative-positive healthy subjects and $\mathrm{TB}$ patients with minimal disease, compared to weak responses in TB patients with advanced disease $[17,35]$. These studies suggest that IFN- $\gamma$ plays an important role in protection against human TB. The observation of antigen-specific Th1-cell responses to MPT64 using both PBMCs and T-cell lines, as judged by antigen-induced proliferation and IFN- $\gamma$ secretion, suggests that MPT64 is relevant to protective immune responses in humans.

Recognition of mycobacterial antigens by CD4+ T cells circulating in peripheral blood is mostly restricted by HLA-DR molecules [36-38]. These molecules are highly polymorphic and vary in their frequency of expression in various populations and ethnic groups. Therefore, an antigen selected as a vaccine candidate against TB should be recognized by Th1 cells in association with multiple allelic products of HLA-DR $[3,17]$. In this study, HLA-DR typing of the donors showed that MPT64 was recognized by $\mathrm{T}$ cells obtained from donors of varied
Table 5. Antigen-induced proliferation (SI) of T-cell line 1 to complex and single secreted antigens of $M$. tuberculosis in the presence of HLA-DR-typed autologous and allogeneic APCs

\begin{tabular}{lllll}
\hline \multirow{2}{*}{ APC and HLA-DR type } & \multicolumn{5}{l}{ SI in response to } \\
\cline { 2 - 5 } & MTCF & Ag85B & MPT64 & MPB70 \\
\hline Autologous $(4,6,52,53)$ & 72 & 55 & 70 & 64 \\
Allogeneic $(4,5,52,53)$ & 10 & 0.8 & 14 & 4.3 \\
Allogeneic $(7,53)$ & 5.9 & 0.9 & 11 & 9.3 \\
Allogeneic $(3,7,52,53)$ & 20 & 1.0 & 30 & 13 \\
Allogeneic $(4,6,52,53)$ & 6.0 & 1.0 & 14 & 8.7 \\
Allogeneic $(2,7,51,53)$ & 40 & 1.0 & 30 & 16 \\
Allogeneic $(3,5,52)$ & 4.5 & 0.5 & 15 & 6.7 \\
Allogeneic $(2,4,51,53)$ & 10 & 1.0 & 14 & 9.5 \\
Allogeneic $(5,7,52)$ & 23 & 1.0 & 40 & 23 \\
\hline
\end{tabular}

Positive responses $(\mathrm{SI}>2)$ are given in italics.

HLA background. These results are encouraging and suggest that within a human population, genetically promiscuous MPT64 epitopes recognized by a high proportion of donors exist. This observation supports the inclusion of MPT64 as candidate antigens in subunit vaccine design against $\mathrm{TB}$.

In addition to antigen-induced proliferation and IFN$\gamma$ secretion, we also tested the CD4+ T-cell lines for cytotoxic activity against MPT64-pulsed monocytes. Usually, CD4+ T cells are considered to be helper cells; however, it has been shown that the Th1 subset of CD4+ T cells can also have cytotoxic activity, recognize macrophages infected with $M$. tuberculosis and kill the intracellular bacteria directly [15]. Our results demonstrate that MPT64reactive cytotoxic CD4+ T-cell lines also secreted IFN- $\gamma$ (table 4). Both of these activities exhibited by $\mathrm{CD} 4+\mathrm{T}$ cells may independently contribute to their protective ability by direct killing of the bacteria-laden monocytes/ macrophages by cytotoxic activity and activation of infected macrophages by IFN- $\gamma$.

Although MPT64 has previously been characterized for antigen-induced proliferation and IFN- $\gamma$ secretion in TB patients and their contacts by Roche et al. [8], to our knowledge, this is the first study of MPT64 in healthy humans with respect to recognition by Th1 cells and, in particular, for cytotoxic activity and HLA restriction analysis of T-cell lines. Furthermore, Roche et al. [8] tested only MPT64 in their study, whereas this is a comprehensive and comparative study showing that the Th1-cell responses induced by MPT64 were comparable to other 
single antigens of M. tuberculosis like Ag85B and MPB70, both of which have previously been proposed as candidate vaccines against TB [3].

\section{Conclusion}

The results presented in this work demonstrate that MPT64 is a Th1-cell-stimulating antigen of M. tuberculosis with ability to induce positive responses in HLAheterogeneous donors. Furthermore, its promiscuous presentation to Th1 cells with cytotoxic activity against antigen-pulsed APCs suggests that MPT64 deserves consideration for inclusion in a vaccine cocktail to protect against human TB.

\section{Acknowledgements}

This work was supported by Kuwait University, Research Grant No. MI02/02. The buffy coats from the donors were provided by the Central Blood Bank, Kuwait. The technical help provided by Fatema Shaban is gratefully acknowledged.

\section{References}

1 Lönnroth K, Raviglione M: Global epidemiology of tuberculosis: prospects for control. Semin Respir Crit Care Med 2008;29:481491.

2 Mokaddas E, Ahmad S, Samir I: Secular trends in susceptibility patterns of Mycobacterium tuberculosis isolates in Kuwait, 19962005. Int J Tuberc Lung Dis 2008;12:319 325.

3 Mustafa AS: Progress towards the development of new anti-tuberculosis vaccines; in Smith LT (ed): Focus on Tuberculosis Research. New York, Nova Science Publishers, 2005, pp 47-76.

-4 Wiker HG, Mustafa T, Malen H, Riise AMD: Vaccine approaches to prevent tuberculosis. Scand J Immunol 2006;64:243-250.

5 Andersen P: Effective vaccination of mice against Mycobacterium tuberculosis infection with a soluble mixture of secreted mycobacterial proteins. Infect Immun 1994;62: 2536-2544.

-6 Malen H, Berven FS, Fladmark KE, Wiker HG: Comparative analysis of exported proteins from Mycobacterium tuberculosis H37Rv. Proteomics 2007;7:1702-1718.

7 Sable SB, Kumar R, Kalra M, Verma I, Khuller GK, Dobos K, Belisle JT: Peripheral blood and pleural fluid mononuclear cell responses to low-molecular-mass secretory polypeptides of Mycobacterium tuberculosis in human models of immunity to tuberculosis. Infect Immun 2005;73:3547-3558.

$>8$ Roche PW, Feng CG, Britton WJ: Human Tcell epitopes on the Mycobacterium tuberculosis secreted protein MPT64. Scand J Immunol 1996;43:662-670.

$\$ 9$ Mustafa AS, Amoudy HA, Wiker HG, Abal AT, Ravn P, Oftung F, Andersen P: Comparison of antigen-specific T-cell responses of tuberculosis patients using complex or single antigens of Mycobacterium tuberculosis. Scand J Immunol 1998;48:535-543.
Al-Attiyah R, Madi N, El-Shamy AS, Herald W, Andersen P, Mustafa AS: Cytokine profiles in tuberculosis patients and healthy subjects in response to complex and single antigens of Mycobacterium tuberculosis. FEMS Immunol Med Microbiol 2006;47: 254-261.

11 Mustafa AS, El-Shamy AM, Madi NM, Amoudy HA, Al-Attiyah R: Cell-mediated immune responses to complex and single mycobacterial antigens in tuberculosis patients with diabetes. Med Princ Pract 2008; 17:325-330.

12 Luo XD, Zhu DY, Chen Q, Jiang Y, Jiang S, Yang C: A study of the protective effect of the DNA vaccine encoding tubercle antigen $85 \mathrm{~B}$ with MPT64 in mice challenged with Mycobacterium tuberculosis. Zhonghua Jie $\mathrm{He} \mathrm{He}$ Hu Xi Za Zhi 2004;27:611-616.

13 Bai Y, Xue Y, Gao H, Wang L, Ding T, Bai W, Fan A, Zhang J, An Q, Xu Z: Expression and purification of Mycobacterium tuberculosis ESAT-6 and MPT64 fusion protein and its immunoprophylactic potential in mouse model. Protein Exp Purif 2008;59:189-196.

14 Locht C, Hougardy JM, Rouanet C, Place S, Mascart F: Heparin-binding hemagglutinin: from an extrapulmonary dissemination factor to a powerful diagnostic and protective antigen against tuberculosis. Tuberculosis (Edinb) 2006;86:303-309.

-15 Bastian M, Braun T, Bruns H, Röllinghoff M, Stenger S: Mycobacterial lipopeptides elicit CD4+ CTLs in Mycobacterium tuberculosis-infected humans. J Immunol 2008; 180 : 3436-3446.

16 Mustafa AS: HLA-restricted immune response to mycobacterial antigens: relevance to vaccine design. Hum Immunol 2000;61: 166-171.

17 Mustafa AS: Biotechnology in the development of new vaccines and diagnostic reagents against tuberculosis. Curr Pharm Biotechnol 2001;2:157-173.
18 Hanif SNM, El-Shamy AM, Al-Attiyah R, Mustafa AS: Whole blood assays to identify Th1 cell antigens and peptides encoded by Mycobacterium-tuberculosis-specific RD1 genes. Med Princ Pract 2008;17:244-249.

19 Al-Attiyah R, Shaban FA, Wiker HG, Oftung F, Mustafa AS: Synthetic peptides identify promiscuous human Th1 cell epitopes of the secreted mycobacterial antigen MPB70. Infect Immun 2003;71:1953-1960.

20 Al-Attiyah R, Mustafa AS: Computer-assisted prediction of HLA-DR binding and experimental analysis for human promiscuous Th1 cell peptides in a novel $24-\mathrm{kDa}$ secreted lipoprotein (LppX) of Mycobacterium tuberculosis. Scand J Immunol 2004;59:16-24.

21 Mustafa AS, Al-Attiyah R, Hanif SNM, Shaban FA: Efficient testing of large pools of $M y$ cobacterium tuberculosis RD1 peptides and identification of major antigens and immunodominant peptides recognized by human Th1 cells. Clin Vaccine Immunol 2008; 15 : 916-924.

22 Mustafa AS: Th1-cell reactivity and HLADR binding prediction for promiscuous recognition of MPT63 (Rv1926c), a major secreted protein of Mycobacterium tuberculosis. Scand J Immunol 2009;69:213-222.

23 Mustafa AS, Shaban FA: Propred analysis and experimental evaluation of promiscuous Th1 cell epitopes of three major secreted antigens of Mycobacterium tuberculosis. Tuberculosis (Edinb) 2006;86:115-124.

24 Mustafa AS, Abal AT, Shaban F, El-Shamy AM, Amoudy HA: HLA-DR binding prediction and experimental evaluation of mycolyltransferase (Ag85B), a major secreted antigen of Mycobacterium tuberculosis. Med Princ Pract 2005;14:140-146.

25 Amoudy HA, Mustafa AS: Amplification of six putative RD1 genes of Mycobacterium tuberculosis for cloning and expression in Escherichia coli and purification of expressed proteins. Med Princ Pract 2008;17:378-384. 
-26 Al-Attiyah R, Mustafa AS, Abal AT, Madi NM, Andersen P: Restoration of mycobacterial antigen-induced proliferation and interferon-gamma responses in peripheral blood mononuclear cells of tuberculosis patients upon effective chemotherapy. FEMS Immunol Med Microbiol 2003;38:249-256.

27 Al-Attiyah R, Mustafa AS: Characterization of human cellular immune responses to novel Mycobacterium tuberculosis antigens encoded by genomic regions absent in $\mathrm{Myco}$ bacterium bovis BCG. Infect Immun 2008; 76:4190-4198.

-28 Al-Attiyah R, Mustafa AS, Abal AT, El-Shamy AM, Dalemans W, Skeiky YAW: In vitro cellular immune responses to complex and newly defined recombinant antigens of $M y$ cobacterium tuberculosis. Clin Exp Immunol 2004;138:139-144.

-29 Mustafa AS, Shaban FA, Abal AT, Al-Attiyah R, Wiker HG, Lundia KEA, Oftung F, Huygen K: Identification and HLA restriction of naturally derived Th1-cell epitopes from the secreted Mycobacterium tuberculosis antigen $85 \mathrm{~B}$ recognized by antigen-specific human CD4+ T cell lines. Infect Immun 2000; 68:3933-3940.
30 Mustafa AS, Shaban FA, Al-Attiyah R, Abal AT, El-Shamy AM, Andersen P, Oftung F: Human Th1 cell lines recognize the Mycobacterium tuberculosis ESAT- 6 antigen and its peptides in association with frequently expressed HLA class II molecules. Scand J Immunol 2003;57:125-134.

31 Wiker HG, Harboe M, Nagai S, Patarroyo ME, Ramirez C, Cruz N: MPB59, a widely cross-reacting protein of Mycobacterium bovis BCG. Int Arch Allergy Appl Immunol 1986;81:307-314.

32 Andersen AS, Lingquist L, Haslov K, Bentzon MW: MPB64 possesses 'tuberculosiscomplex'-specific B- and T-cell epitopes. Scand J Immunol 1991;34:365-372.

33 Harboe M, Nagai S, Patarroyo ME, Torres ML, Ramirez C, Cruz N: Properties of proteins MPB64, MPB70, and MPB80 of $\mathrm{Myco-}$ bacterium bovis BCG. Infect Immun 1986; 52:293-302.
4 Oettinger T, Andersen AB: Cloning and Bcell-epitope mapping of MPT64 from $\mathrm{Myco}$ bacterium tuberculosis H37Rv. Infect Immun 1994;62:2058-2064.

35 Mustafa AS: Development of new vaccines and diagnostic reagents against tuberculosis. Mol Immunol 2002;39:113-119.

36 Mustafa AS, Lundin KEA, Meloen RH, Shinnick TM, Oftung F: Identification of promiscuous epitopes from the mycobacterial 65 $\mathrm{kDa}$ heat shock protein (HSP65) recognized by human CD4+ T cells of the M. leprae memory repertoire. Infect Immun 1999;67: 5683-5689.

37 Mustafa AS, Lundin KEA, Meloen RH, Oftung F: Crossreactive epitopes and HLA-restriction elements in human $\mathrm{T}$ cell recognition of the Mycobacterium leprae $18-\mathrm{kD}$ heat shock protein. Clin Exp Immunol 2000;120: 85-92.

38 Oftung F, Lundin KEA, Geluk A, Shinnick TM, Meloen R, Mustafa AS: Primary structure and $\mathrm{MHC}$ restriction of peptide-defined $\mathrm{T}$ cell epitopes from recombinantly expressed mycobacterial protein antigens. Med Princ Pract 1997;6:66-73. 